\title{
Transparência recompensada
}

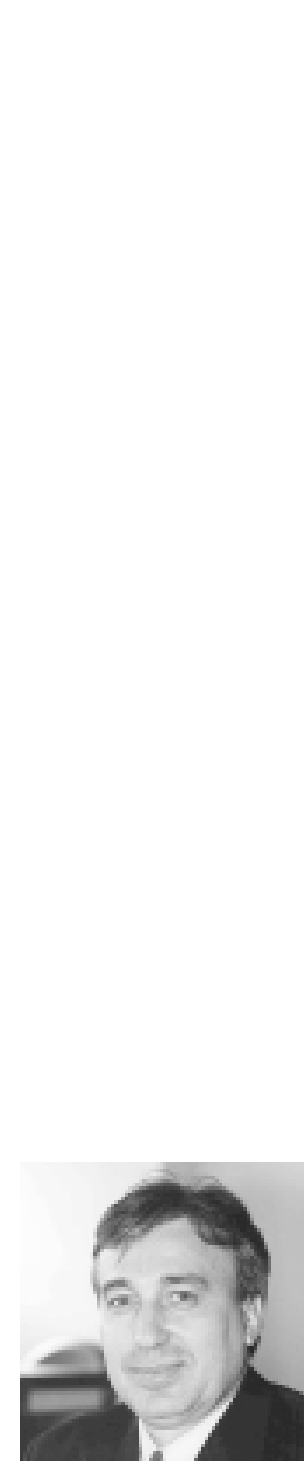

Fábio Gallo Garcia FGV-EAESP
A s práticas de má-gestão de grandes corporações, que levaram aos escândalos financei ros deste início de século, abalaram não só um seleto grupo de investidores mundiais, mas também a opinião pública. Empresas como Sunbean, Enron e WorldCom irradiaram uma onda de preocupação e desconfiança no mundo corporativo, trazendo para o primeiro plano questões que envolvem ética na condução dos negócios.

0 fato é que essas empresas não tinham um histórico de boas práticas de governança corporativa e de transparência na apresentação de demonstrativos econômico-financeiros. Em contrapartida, constituem exemplos de um modelo de gestão focado no incremento do resultado financeiro de curto prazo, que não considera a presença da empresa em um sistema maior de geração de valor, que envolve os acionistas, a comunidade, o mercado, os clientes e os funcionários. Essas empresas mantinham um processo truncado de comunicação com o mercado.

Depois dos escândalos, a tendência de mudança nas práticas dos mercados de capitais foi acelerada e a necessidade de boas práticas de governança corporativa tornou-se dramática. Tornou-se cada vez mais relevante a existência de processos abertos de comunicação entre a empresa e seus investidores.

Pesquisas recentes indicam que três elementos centrais vêm ocupando a atenção dos investidores. 0 primeiro é a transparência dos demonstrativos contábeis das empresas. 0 segundo é a prioridade atribuída às reformas destinadas a reconstituir a confiança no sistema financeiro. $\mathrm{E}$ o terceiro elemento refere-se ao reconhecimento, por parte dos investidores, de que a governança corporativa está no centro de qualquer decisão de investimento.

Um exemplo local comprova essa tendência no mercado de capitais. Trata-se de uma ação da Bovespa, que lançou, em dezembro de 2000, um segmento denominado Novo Mercado. A inclusão das empresas nesse segmento depende de seu grau de comprometimento com práticas de governança corporativa. Segundo a instituição, tais práticas envolvem um conjunto de normas de conduta para as empresas, os administradores e os controladores, reconhecidas como vitais para a valorização das ações e de outros ativos por elas emitidos.

Essas e outras iniciativas revelam que 0 mercado de capitais está mais cauteloso e que a transparência tende a ser cada vez mais recompensada. De fato, há bons motivos adicionais para as empresas aderirem a essas práticas: estudos mostram que a transparência contábil implica maior valorização das ações da empresa. A expectativa é que ocorra um estímulo adicional para que nossas empresas se comprometam com o desenvolvimento de um processo aberto de comunicação com todos os seus stakeholders. 